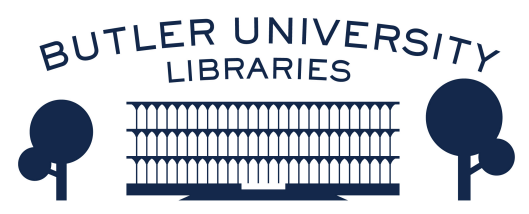

Journal of Hindu-Christian Studies

\title{
Non-Dual Belonging: Conversion, Sanskritization and the Dissolution of the Multiple in Advaita Missionary Movements
}

Reid B. Locklin

St. Michael's College, University of Toronto

Follow this and additional works at: https://digitalcommons.butler.edu/jhcs

\section{Recommended Citation}

Locklin, Reid B. (2015) "Non-Dual Belonging: Conversion, Sanskritization and the Dissolution of the Multiple in Advaita Missionary Movements," Journal of Hindu-Christian Studies: Vol. 28, Article 9. Available at: https://doi.org/10.7825/2164-6279.1608

The Journal of Hindu-Christian Studies is a publication of the Society for Hindu-Christian Studies. The digital version is made available by Digital Commons @ Butler University. For questions about the Journal or the Society, please contact cbauman@butler.edu. For more information about Digital Commons @ Butler University, please contact digitalscholarship@butler.edu. 


\title{
Non-Dual Belonging: \\ Conversion, Sanskritization and the Dissolution of the Multiple in Advaita Missionary Movements
}

\author{
Reid B. Locklin \\ St. Michael's College, University of Toronto
}

IN a series of articles from 1957 until his death in 1979, the influential Indologist Paul Hacker advanced the claim that those Indian traditions generally classified as open and tolerant should in fact be labeled "inclusivist." Rather than engaging religious or philosophical opponents in their integrity, he suggested, such traditions subordinated such others and assumed them into their own doctrinal systems. This term was deployed polemically by Hacker against a number of Hindu traditions, above all the modern forms of Advaita Vedānta advanced by the likes of Swami Vivekananda (1863-1902) and Sarvepalli Radhakrishnan (1888-1975). This broad thesis has been widely criticized, not least by Hacker's translator and editor Wilhelm Halbfass. $^{2} \quad$ Particularly suspect is Hacker's sweeping contrast between inclusivism and tolerance, and the correlations from these positions to Indian and European thought, respectively. As Halbfass has demonstrated, both styles of argument, among others, can be adduced in Hindu, Christian and Muslim traditions; the harder and more important task is, in his telling, to attend to the distinctive strategies of engagement with religious others in any particular text or tradition.

Such critiques notwithstanding, it remains true that some type of inclusivist accommodation of religious difference can be adduced in many modern Hindu traditions. So also, in at least some cases, apparently irenic, inclusivist accommodation can shade into more assertive images of conversion or conquest, particularly in those movements that have taken missionary shape outside the Indian subcontinent. Several important studies, including especially Reinhart Hummel's landmark 1987 monograph Indische Mission und neue Frömmigkeit im Westen and Carl Jackson's 1994 Vedanta for the West, have traced such diverse movements as the Ramakrishna

Reid B. Locklin holds an associate professorship in Christianity and the Intellectual Tradition at St. Michael's College and the Department of Religion, University of Toronto. He is the author of Spiritual but Not Religious? (Liturgical Press, 2005), Liturgy of Liberation (Peeters, 2011) and other works in theology, Hindu-Christian studies and spirituality. He has also recently co-edited two works in the scholarship of teaching and learning, Teaching Civic Engagement (Oxford University Press, 2016) and Comparative Theology in the Millennial Classroom (Routledge, 2016). He can be reached at reid.locklin@utoronto.ca. 
Mission, the Self-Realization Fellowship, the International Society of Krishna Consciousness, Transcendental Meditation and other modern Hindu missions as they spread throughout North America and Europe. ${ }^{3}$ In 1999, the Indian theologian C.V. Mathew published a more critical account of what he viewed as a single, relatively coherent "Saffron Mission" in both India and the West. This has been followed by several more pointed and polemic studies by a Salesian priest, J. Kuruvachira, between 2006 and 2008. ${ }^{4}$ For Mathew, the emergence of distinctively modern movements like the Ramakrishna Mission abroad, as well as the reconversion work of the VHP and other Hindu nationalist organizations in India, can ultimately be traced back to much older patterns of Sanskritization and Brahminization embodied in the Vedic dictum krnvanto viśvamäryam, "Let the whole world become Aryan" (Rg-Veda 9.63.5). ${ }^{5}$ While Kuruvachira more strongly emphasizes the novelty of this development in the modern period, he also interprets processes of Sanskritization, explicit (re-)conversion rites developed by Hindu nationalists in the modern period, such as suddhi ("purification") and parāvartan ("welcoming"), and especially Swami Vivekananda's oft-quoted exhortions, "Up, India, conquer the world with your spirituality," and "the world must be conquered by India" as, collectively, an unambiguous mandate to convert. ${ }^{6}$ "In the course of time," Kuruvachira writes, "increased travel facilities, modern communications networks, globalisation, rise of Hindu cultural nationalism, better organisation and animation of the Hindu diaspora and so on have contributed greatly in making Hinduism emerge as an 'aggressive' missionary religion, seeking followers not only in India but also overseas, especially in the West."7

What, however, is the precise nature of conversion in these Hindu traditions? In his 1987 study, Hummel made the observation that such conversions only rarely take the form of a straightforward change of religious belonging; instead, they more closely resemble gradual acculturation, in which members slowly shed prior religious identities without ever formally renouncing them. ${ }^{8}$ Arvind Sharma's recent monograph, Hinduism as a Missionary Religion advances a similar claim. ${ }^{9}$ Sharma acknowledges a prevailing consensus that Hindus remained "non-missionary" at least well into the modern era; nevertheless, he contends against this consensus that "Hinduism has always possessed a missionary character." ${ }^{10}$ He locates some of the most compelling evidence in the Vedic and Classical periods, adducing not only the Rg-Veda exhortation noted by Mathew, but other Vedic passages, the Manusmrti and the epic literature to suggest that foreigners could be and not infrequently were re-construed as "lapsed Hindus," rendering them eligible for incorporation into Hindu tradition and into the twice-born castes, more particularly. ${ }^{11}$ Even here, however, sharma finds the received terminology an obstacle-especially the language of conversion. Parsing terms carefully, he insists that, even as a "missionary religion," Hinduism does not "seek converts" in a traditional sense; it re-defines conversion itself in non-exclusive terms as "acceptance of a universal point of view." ${ }^{12}$ Stated another way, there is and has been "conversion" to Hinduism, but the distinctive character of Hinduism transforms the meaning of the term "conversion." 
In this essay, I explore the theology of conversion and religious belonging that emerges from the teachings of several contemporary missionary traditions associated with the non-dual tradition of Advaita Vedānta. In the first section, I draw a contrast between two broad frameworks within which to understand a transformation of religious belonging: "conversion-over" and "conversionup." In the second section, I return to Mathew's notion of Sanskritization as a resource for understanding the dynamics of belonging in these traditions. These traditions, I contend, do advance a specific form of religious belonging-albeit one that implies the sublation of rival points of view rather than their explicit exclusion.

\section{Conversion-Over and Conversion-Up}

Some of the difficulties with Arvind Sharma's study, like the earlier contributions of Hummel, Jackson, Mathew, Kuruvachira and others, follow not only from the ambiguous meaning of "conversion," but also the ambiguity of yet another defining term, namely "Hinduism." Though some continue to insist that Hinduism either has existed eternally or was the invention of the British colonial project, an increasing body of scholarship contends that the construction of modern Hinduism emerged from a complex historical process of consolidation and harmonization that perhaps began in medieval and early modern India, even if it took a distinctive shape under the British Raj. ${ }^{13}$ One point that seems certain is that, prior to the medieval period, what we now call Hinduism consisted of many different traditions, which contested as vigorously with one another as with Buddhists or Jains. In part for this reason, I propose focusing not on "Hinduism" as such, but only on the Advaita Vedānta tradition of the eighthcentury teacher Śańkarācārya and his many, diverse successors in the modern and contemporary periods. Such a choice may appear arbitrary, but there are intrinsic reasons for such a focus. Not least, these include the prominence of Swami Vivekananda and his Ramakrishna Mission in any discussion of Hindu missionary movements in the modern period. I also judge that it makes good sense to seek clarity on a broad point of interpretation by attending first to a single, delimited case study. Far from enshrining Advaita as the true core of Hinduism, such an approach can bring out the historical contingency of the tradition and its complex relations with other traditions in the broader Hindu stream.

The fundamental teaching of Advaita-that is, the ultimate non-difference of self and God, of multiplicity and unity-also renders these traditions, at least arguably, particularly prone to ambivalence on questions of religious belonging. At the 1893 World's Parliament of Religions, for example, Swami Vivekananda famously eschewed conversion, declaring, "Do I wish that the Christian would become Hindu? God forbid. Do I wish that the Hindu or Buddhist would become Christian? God forbid." ${ }^{14}$ Yet, he did not hesitate to initiate disciples and to describe his mission in strongly evangelical terms, including spiritual conquest and even religious conversion. ${ }^{15}$ One of his successors in the movement, Swami Budhananda, revels in this apparent contradiction, describing the Ramakrishna Mission as "a missionary organization with an intriguing apathy for proselytization." 16 For critics, on the other hand, such mixed messages suggest incoherence or, at worst, deliberate 
deceit. ${ }^{17}$ Does the Ramakrishna movement promote conversion, or not?

The answer, I think, is: yes, the movement works for religious conversion, but the form of conversion it propagates is not primarily a conversion from one tradition over to another one. Echoing Sharma's notion of conversion to a "universal viewpoint," I would term the kind of conversion we witness in these traditions "conversion-up."18

To trace the dynamics of conversion-up in Advaita traditions, the interpreter need not and indeed should not focus exclusively on the term "conversion," much less on rough analogues like spiritual conquest, śuddhi or parāvartan; one should look instead at these traditions' central doctrines of personal transformation, as they are described and promoted by movement leaders and devotees. ${ }^{19}$ Consider, for example, the ubiquitious mantra from Bṛhadāranyaka Upanișad 1.3.28, recited often after teaching in the Ramakrishna Mission and many other modern Hindu settings:

asato mā sadgamaya//tamaso mā
jyotirgamaya//mrtyormā amrtam gamaya
"Lead [us] from the unreal to the real, from
darkness to light, from death to
immortality."

Striking in this single mantra is the strong sense of asymmetry between unreal and real, darkness and light, death and immortality, as well as the concrete possibility of graded progress upwards from the lower to the higher categories. This, at least, is precisely how Swami Vivekananda typically speaks of religious transformation, particularly when situating the non-dual teaching of Advaita in relation to other religious traditions both within and without the Hindu fold. "To the Hindu," he insisted at the Parliament, "man [sic] is not traveling from error to truth, but from truth to truth, from lower to higher truth." ${ }^{20}$ Vivekananda did not hesitate to assign definite grades to different stages of development, with Dvaita or theist religious teachings at the lowest level on the ladder, Visisțādvaita or panentheist teachings in the middle, and Advaita, the perfect non-dualism of innermost self and impersonal God, as the final stage and perfect fulfillment. ${ }^{21}$ But this scheme of classification cuts across any given religious tradition as well as between them. ${ }^{22}$ Hence, though Vivekananda strongly encourages personal and collective evolution in the direction of Advaita, the unfolding of such change is primarily up from one level of understanding to another, rather than over from one tradition to another.

One particularly illuminating example of Vivekananda's stance toward other religions can be found in a speech from 1900, in which he asks a question rich with missionary implications: "Is Vedanta the Future Religion?" ${ }^{23}$ His initial answer seems very irenic and congenial, for he asserts that, "with all its emphasis on impersonal principles, Vedanta is not antagonistic to anything." ${ }^{24}$ Hence, it cannot be seen as a competitor to the other great religions of the world. At a deeper level, however, Vivekananda also questions whether Vedānta could qualify as a "future religion" on other grounds: not because of a presumed equality of religions, but because Vedānta cannot really be regarded as "religion" at all. ${ }^{25}$ It is instead the highest reality behind all individual religious claims, a saving knowledge of the way things actually are, now 
and eternally. In the light of this highest truth, particular positive religions can only be dismissed as mere "kindergartens of religion" at best and "foolish beliefs and superstitions" at worst. $^{26}$ "The hour comes," Vivekananda declares at the end of his address, "when great men [sic] shall arise and cast off these kindergartens of religion and shall make vivid and powerful the true religion, the worship of the spirit by the spirit." ${ }^{27}$ Vedānta is not antagonistic to other religions precisely because it is the sole "true religion" to which all of them point, a reality so sublime that it transcends the category of "religion" itself.

This vision of conversion-up found a more recent expression at a conference hosted in 2013 to celebrate the $150^{\text {th }}$ anniversary of Swami Vivekananda's birth and $120^{\text {th }}$ anniversary of his addresses to the Parliament. The conference organizers adopted memorable phrases from Vivekananda's speeches to set the theme for the event: "Help and not fight," "Assimilation and not destruction." As one of the prominent Swamis at the conference explained, the religions of the world are like food, or like soil: the seed of truth absorbs them as it grows into its fullness as a flowering plant. $^{28}$ In another analogy from the same speech, religions are like clocks, here to be corrected from time to time by the mystics who have realized the highest truth. In neither case is the truth of these religions simply negated; indeed, the same speaker suggested that one could and perhaps should practice multiple religions. But if one does so, the goal is to take on the spirit of those religions, to assimilate their essence, and thereby to achieve the highest realization of Advaita. It is not conversion, if conversion means conversion- over to a new, exclusive form of religious belonging. It is, instead, conversion-up.

\section{Looking More Closely at Sanskritization}

Another term that might be employed to describe this distinctive, Advaita notion of conversion is also a controversial one: Sanskritization. As I noted briefly in my introduction to this essay, Mathew introduces the interrelated themes of "Sanskritization," "Aryanization" and "Brahminization" to give his account of mission and conversion in modern Hinduism interpretative heft. Drawing on the work of Sarvapalli Radhakrishnan, the anthropologist M.N. Srinivas, and an anonymous 1913 article from The Hindu Review, Mathew suggests that "Sanskritization" involves a process of cultural transformation and, in Radhakrishnan's terms, the "gradual civilising" of lower castes, tribal communities and other cultures of South and Southeast Asia according to an ideal of perfect Brahminhood. ${ }^{29}$ For Mathew, such a paradigm provides a broad historical background and justification for his inquiry into modern Hindu missionary movements. That is, the notion of Sanskritization functions primarily to illustrate that ancient and modern Hinduism possesses its own indigenous models of mission and conversion, and only secondarily to describe how it might render such models conceptually distinct.

As a first step in this direction, we can note that modern, critical theories of Sanskritization do not entirely support the simple, hierarchical image propounded by Radhakrishnan and deployed by Mathew in his description of Hindu missionary movements. When Srinivas employed the principle in his anthropological work, for example, he used it to describe not a 
doctrine of strict assimilation, but a dynamic process by which caste groups self-consciously emulate Brahmin or other high-caste practices in order to advance their own social status, a process akin to-if sometimes in tension withthe process of Westernization under the British Raj. $^{30}$ Like Westernization, this transformation never flowed in only one direction:

Throughout Indian history Sanskritic Hinduism has absorbed local and folk elements and their presence makes easier the further absorption of similar elements. The absorption is done in such a way that there is a continuity between the folk and the theological or philosophical levels, and this makes possible both gradual transformation of the folk layer, as well as the 'vulgarization' of the theological layer. ${ }^{31}$

Importantly for Srinivas's analysis, Sanskritization was only rarely promoted by Brahmins, who often viewed such cultural processes as a threat to their privilege. Rather, the primary agents were those who wanted to advance themselves, and its specific shape varied enormously, depending upon local context, so much so that Srinivas eventually attempted to generalize the concept and to divest it of any necessary, substantive connection with Brahminism. ${ }^{32}$

Sheldon Pollock's more recent work on the emergence of a "Sanskrit Cosmopolis" in South and Southeast Asia between 300 and 1300 represents a second insightful resource in this regard. ${ }^{33}$ Pollock traces a process of Sanskritization in a very literal sense: namely, the expansion of Sanskrit from its earlier liturgical and scholastic domains to the realm of the public and the political, specifically in the proliferation of Sanskrit political inscriptions and the allied development of classical poetic forms ( $k \bar{a} v y a)$. Sharply critical of functionalist approaches-including that of Srinivas-that attempt to explain the spread of such cultural forms by appealing to their high status or their utility as tools of social legitimation, Pollock instead appeals directly to the intrinsic "textuality" of classical Sanskrit as "a language of cosmopolitan stature." ${ }^{34}$ Certain features of this liturgical language, he claims, rendered it particularly suitable for bestowing a "permanent, indeed eternal, expression" upon the fame of political rulers: the stability of its grammar, its aesthetic qualities of metaphor and other figures of sense, its capacity "to interpret, supplement, [and] reveal reality," "to make the real somehow superreal by poetry." ${ }^{35}$ This cultural achievement was never imposed through coercive power or any unified religious vision; it spread by means of "some far less obvious process of cultural imitation and borrowing," a process co-constitutive with the emergence of the textual form itself. $^{36}$ Contrary to the implicit and explicit claims made through the Sanskrit idiom in this period, moreover, this achievement was historically contingent from beginning to end, and it was emphatically not eternal, for Sanskrit was eventually displaced by various vernaculars.

Neither Srinivas nor Pollock is beyond reproach, of course, ${ }^{37}$ and it would be difficult if not impossible to argue that modern Advaita mission movements engage directly in one or another process of literal Sanskritization. ${ }^{38}$ Indeed, both theorists would seem seriously to challenge any use of this concept in terms of deliberate propagation, emphasizing as they do the relative autonomy and self-conscious 
patterns of imitation of those who become "Sanskritized."

At the same time, I would contend that it is precisely these aspects of autonomy and imitation that make the metaphor of Sanskritization an apt one for describing conversion in these Advaita movements. Consider the case of the Chinmaya Mission, founded in 1951 by Swami Chinmayananda (1916-1993). In his important work A Manual of Self-Unfoldment, Chinmayananda offered the following account of Hinduism's diffusion throughout Asia:

One of the particularities which deserves mention is that the Hindus never thrust their religion forcibly or by trickery on other people. Peace, love, compassion, sympathy and service were their watchwords. That point will be more significant later on when the actual details of the Hindu religion are discussed. The people of the foreign countries welcomed and hailed the superior culture of the Hindus. Thus one may say that Hinduism is the mother of civilisation in the East ... This great religion of the Hindus is a Mighty force for universal good. That is why this religion has had such a glorious and brilliant record of past achievements and why the Hindus believe that their religion is destined for a greater and more glorious future. ${ }^{39}$

As he promises, Chinmayananda clarifies what he means by the Hindu "religion" a few pages further along in the same work: it is, of course, none other than Advaita Vedānta, the universal non-dual teaching of the Hindu Upanișads and epics, as well as of the Christian Bible and all authentic scriptures worldwide. ${ }^{40}$ Because of its universality, its glory and its self-evident superiority, this religion need not be "thrust" on other people by force or deceit. The primary agency for its transmission lies not with its preachers or teachers, but with those who recognize its intrinsic value and embrace it as their own.

This idea is made clear later in the same volume, in a description of the small Study Groups that would become one of the signature features of the Chinmaya Mission. A question is raised: "Study Group. Is it a subtle means of conversion to the Hindu faith?" To this, the authors give the following response:

Not at all. Vedanta is not sectarian in appeal. As experienced by a number of members of study groups all over the world, this study makes one a better individual irrespective of whatever faith he or she may belong to. Vedanta does not seek converts. It is a great catalyst for a better understanding and self integration. Its appeal is to the intellect and its application is universal. Hence is it used for self-improvement and never for conversion. ${ }^{41}$

The language of "self-improvement," like the related idiom of "civilization," readily evokes images of Sanskritization. Just as Srinivas distinguished between Sanskritic theology or philosophy at one level and folk religion at another, so also here the teaching of Vedānta is situated at a higher level relative to participants' individual faith positions, such that it can serve as a catalyst for their intellectual understanding and ever greater 
personal integration. Participation in study groups simply "makes one a better individual."

Lest we underestimate the normative character of such self-improvement, we can turn to the example of Swami Chinmayananda's former disciple Swami Dayananda Saraswati (1930-2015). Dayananda, like Vivekananda and Chinmayananda, was convinced that Vedānta represents a timeless truth with the power to correct, purify and ultimately sublate other religious claims. A good example of his rhetorical strategy in this regard can be found in a short work entitled $A$ Vedantin's View of Christian Concepts, in which he takes up a range of central Christian claims. ${ }^{42}$ Some central doctrines, such as creation ex nihilo, Dayananda dismisses as unintelligible; others, like the key narratives of salvation history, he interprets allegorically in the light of Advaita. ${ }^{43} \mathrm{He}$ claims that traditions as Christianity are "not totally off the mark," but that they must be re-imagined and reunderstood to prepare for the profound "shift in thinking" required by Vedānta. ${ }^{44}$ As Vivekananda did before him, so also Dayananda suggested that the truth of Advaita is not new; it is already at work beyond the boundaries of India or Hinduism:

Wherever it is, if there is an equation: you are the whole, that's Vedānta, in whichever language. And it's available in whichever culture. That is Vedānta. Only thing is, we have a teaching tradition for that, to make that happen ... And in other cultures it would remain as mysticism. They would be called mystics, if anyone made a statement like that. ${ }^{45}$
Dayananda goes on to identify Meister Eckhart as precisely such a "mystic" who somehow "had some insight" outside any explicit connection to Advaita tradition. To be truly enduring and effective, however, such generalized mysticism must evolve into a "teaching tradition" like that of Vedānta. ${ }^{46}$ Total replacement is out of the question. On the contrary, any religious transformation from Christianity to Advaita would necessarily involve assimilation and bringing to perfection of the best that Christians themselves have to offer.

\section{Non-Dual Belonging}

In her introduction to the edited collection, Many Mansions?, Catherine Cornille notes that, although not all religious traditions require exclusive allegiance across the whole of life, most require "single-minded commitment" in those areas that lie within "their own area of religious expertise." ${ }^{47}$ Where a tradition does require a more encompassing commitment-as would be the case for most forms of Christianity-she suggests three ways of harmonizing such commitment with some form of practice or belonging in another tradition: belief in a shared, "ultimate religious experience" at the foundation of both (or all) traditions; absorbing the "hermeneutical framework" of the second tradition into the superior "symbolic framework" of the home tradition; or an acceptance of the mutual "complementarity" of the two traditions, each in their own sphere of competence. ${ }^{48}$

An Advaita theology of "conversion-up," as I have explored it here, would seem to bear some similarities to all three of these hermeneutical options, without being strictly identical with any one of them. Is this, then, an 
explicit theology of multiple religious belonging? In the Chinmaya Mission, disciples do identify with multiple traditions, and they are encouraged to do so; so also, texts and teachings from multiple traditions are frequently deployed by senior Chinmaya Mission teachers in the propagation of Advaita. To offer just one example: in the summer of 2007, a visiting ācārya from the Mission concluded a five-day yajña or series of discourses on the Bhagavad-Gitā in the Greater Toronto Area with a day-long retreat entitled, "The Wisdom of the Sages." ${ }^{49}$ The form of the lecture was a series of PowerPoint slides with short maxims drawn from great saints and mystics throughout the ages. Many of these were drawn from sources one might expect from an Advaita missionary movement: Swami Chinmayananda, Swami Vivekananda, Krishna and Arjuna, the Buddha. Other maxims reached further afield to include the Muslim poet Rumi, the Gospel of John, Abraham Lincoln, tenets of traditional African religion and so on. The teaching of Vedānta was, at this level, explicitly plural, offering a vision of multiple religious

\section{Notes}

${ }^{1}$ See especially Paul Hacker, Inklusivismus: Eine indische Denkform, ed. G. Oberhammer (Wien: Institut für Indologie der Universität Wien, 1983).

2 Wilhelm Halbfass, 'Inclusivism' and 'Tolerance' in the Encounter between India and the West," in India and Europe: An Essay in Understanding (Albany, NY: State University of New York Press, 1988), 403-18.

${ }^{3}$ Reinhart Hummel, Indische Mission und neue Frömmigkeit im Westen: Religiöse Bewegungen Indiens in westlichen Kulturen (Stuttgart: Verlag belonging to its disciples in the form of its multiple PowerPoint slides. At the same time, the otherness of these traditions was never fully acknowledged. Nor was it categorically denied. It was, instead, dissolved in the process of instruction, as each successive wisdom tradition added further dimensions to the single, non-dual truth of Advaita Vedānta.

Viewed through the lens of a presentation like the "Wisdom of the Sages," it makes sense that potential disciples need not fear that they may be asked to become Hindu. From the point of view of the Chinmaya Mission, they need never be so asked, because the language of the teaching is deployed as being universal, eternal and intrinsically oriented to, in Pollock's terms, interpret, supplement and reveal new dimensions of participants' lives. The point is not to "convert," if that means shifting horizontally, as it were, from one religion to another; it is to become reinterpreted, refined, and reinscribed in the higher teaching of Advaita. Belonging is, in this case, neither singular nor multiple. It is non-dual.

W. Kohlhammer, 1980); Carl S. Jackson, Vedanta for the West: The Ramakrishna Movement in the United States (Bloomington and Indianapolis, IN: Indiana University Press, 1994).

${ }^{4}$ C.V. Mathew, The Saffron Mission: A Historical Analysis of Modern Hindu Missionary Ideologies and Practices (Delhi: ISPCK, 1999) http://dx.doi.org/2027/mdp.39015052286211; and J. Kuruvachira, "Hinduism as a Missionary Religion," Mission Today 8 (2006): 265-84; ; idem., "Hinduism's World Mission," Mission Today 9 (2007): 39-56; ; idem., Hindu Nationalists of Modern India: A Critical Study of the Intellectual Genealogy of Hindutva (Jaipur: Rawat 
Publications, 2006) http://dx.doi.org/2027/ mdp.39015069168238; and ; idem., Politicisation of Hindu Religion in Postmodern India (Jaipur: Rawat Publications, 2008). See also C.V. Mathew, Neo-Hinduism: A Missionary Religion (Madras: Church Growth Research Centre, 1987) http://dx.doi.org/2027/mdp. 390150 21706711; P.D. Devanandan, "Hindu Missions to the West," International Review of Missions 48 (1959): 398-408. http://dx.doi.org/10.1111/ j.1758-6631.1959.tb02414.x; idem., The Gospel and Renascent Hinduism, I.M.C. Research Pamphlets 8 (London: SCM Press, 1959); and Wendell Thomas, Hinduism Invades America (New York: Beacon Press, 1930).

${ }^{5}$ Mathew, Saffron Mission, esp. 6, 36-40, 121, 19294, 196-97, 203, 284-85.

6 Kuruvachira, "Hinduism as a Missionary Religion,” 266-70.

${ }^{7}$ Kuruvachira, "Hinduism's World Mission," 3940.

${ }^{8}$ Hummel, Indische Mission, esp. 17-18, 239-40.

9 Arvind Sharma, Hinduism as a Missionary Religion (Albany, NY: State University of New York Press, 2011).

${ }^{10}$ Ibid., 129.

${ }^{11}$ Ibid., esp. 65-83. See also Arvind Sharma, "Ancient Hinduism as a Missionary Religion," Numen $39 \quad$ (1992): $175-92$. http://dx.doi.org/10.1163/156852792X00023 ${ }^{12}$ Sharma, Hinduism as a Missionary Religion, 134. 13 On this point, see especially Andrew Nicholson, Unifying Hinduism: Philosophy and Identity in Indian Intellectual History (New York: Columbia University Press, 2010), as well as Brian K. Pennington, Was Hinduism Invented? Britons, Indians, and the Colonial Construction of Religion (Oxford and New York: Oxford University Press, 2005). http://dx.doi.org/
10.1093/0195166558.001.0001

14 Swami Vivekananda, "Addresses at the Parliament of Religions," in The Complete Works of Swami Vivekananda, vol. I (Calcutta: Advaita Ashrama: 1970), 24. http://dx.doi.org /2027/ mdp.39015001150088

${ }^{15}$ See especially Mathew, Saffron Mission, 134-40; and Paul Hacker, "Vivekananda's Religious Nationalism," in Philology and Confrontation: Paul Hacker on Traditional and Modern Vedanta, ed. Wilhelm Halbfass (Albany, NY: State University of New York Press, 1995), 319-36.

16 Swami Budhananda, The Ramakrishna Movement: Its Meaning for Mankind (Calcutta: Advaita Ashrama, 1980, 1994), 38. http://dx.doi.org/2027/inu.30000010168213

${ }^{17}$ E.g. Thomas, Hinduism Invades America, 118-19; Jackson, Vedanta for the West, 74; and Kuruvachira, Hindu Nationalists, esp. 52-56, 6061.

${ }^{18}$ Though I did not know it at the time that I first formulated this language, this distinction was anticipated by Sarvapalli Radhakrishnan and T.M.P. Mahadevan, the latter of whom distinguished between "horizontal" and "vertical" conversion to make sense of the life and teaching of Mohandas K. Gandhi. See Sharma, Hinduism as a Missionary Religion, 58, $151 n$.

${ }^{19}$ See also Plamthodathil S. Jacob, "Hindu and Christian: Conversions and Transformations," in Conversion in a Pluralistic Context: Perspectives and Perceptions, ed. Krickwin C. Marak and Plamthadathil S. Jacob (Pune: CMS/ISPCK, 2000), 86-111. http://dx.doi.org/2027/mdp.39015050513277

${ }^{20}$ Vivekananda, “Addresses," 17.

21 See, e.g., Swami Vivekananda, Swami Vivekananda, What Religion Is: In the Words of 
Vivekananda, ed. Swami Vidyatmananda (Kolkata: Advaita Ashrama, 1972), 105-16; Mathew, Saffron Mission, 124-25.

22 See Anantanand Rambachan, "Swami Vivekananda: A Hindu Model for Interreligious Dialogue," in Interreligious Dialogue, ed. M. Darrol Bryant and Frank Flinn (New York: Paragon House, 1989), 9-19. http://dx.doi.org/2027/mdp.39015029764969; and Francis X. Clooney, "Hindu Views of Religious Others: Implications for Christian Theology," Theological Studies 64 (2003): 320-23. http://dx.doi.org/10.1177/004056390306400204 ${ }^{23}$ Swami Vivekananda, "Is Vedanta the Future Religion?", in Complete Works, vol. VIII, 122-41.

${ }^{24}$ Ibid., 122.

${ }^{25}$ Ibid., 122-25.

${ }^{26}$ Ibid., 138-41.

${ }^{27}$ Ibid., 141.

${ }^{28}$ Swami Chetananda, "Help, Assimilation and Harmony from a Vedānta Point of View," Chicago Calling: $150^{\text {th }}$ Birth Anniversary Celebration of Swami Vivekananda, Chicago, IL, 10 November 2013.

${ }^{29}$ Mathew, Saffron Mission, 37-40.

${ }^{30}$ M.N. Srinivas, "A Note on Sanskritization and Westernization," in Caste in Modern India and Other Essays (Bombay: Asia Publishing House, 1962), 42-62. http://dx.doi.org/2027/ mdp.39015008375407; idem., "The Cohesive Role of Sanskritization," in The Oxford India Srinivas (Delhi: Oxford University Press, 2009), 221-35.

31 Srinivas, "Sanskritization and Westernization," 60.

${ }^{32}$ See Vineeta Sinha, "Problematizing Received Categories: Revisiting 'Folk Hinduism' and 'Sanskritization.'" Current Sociology 54 (2006): 100-103. http://dx.doi.org/10.1177/0011392106058836

${ }^{33}$ For the purposes of this essay, I have drawn my exposition of Pollock's theory from his article "The Sanskrit Cosmopolis, 300-1300: Transculturation, Vernacularization and the Question of Ideology," in Ideology and Status of Sanskrit, ed. Jan E.M. Houben (Leiden, New York and Köln: E.J. Brill, 1996) http://dx.doi.org/2027/mdp.39015038133941. See also the fuller development of this argument in idem., The Language of the Gods in the World of Men: Sanskrit, Culture, and Power in Premodern India (Berkeley: University of California Press, 2006).

${ }^{34}$ Pollock, "Sanskrit Cosmopolis," 239, 243.

${ }^{35}$ Ibid., 209-17, 238-43, quotations at 240, 212, 242.

${ }^{36}$ Ibid., 216.

37 For criticisms of Srinivas, see Pollock, Language of the Gods, 513-14, and Sinha, "Problematizing Received Categories," 103-109; on Pollock, see David Shulman, "Review Essay: The Language of the Gods in the World of Men by Sheldon Pollock," Journal of Asian Studies 66 (2007): 819-73. http://dx.doi.org/10.1017/ S0021911807000976; and Rebecca Gould, "How Newness Enters the World: The Methodology of Sheldon Pollock," Comparative Studies of South Asia, Africa and the Middle East 28 (2008): 533-559. http://dx.doi.org/10.1215/1089201x-2008-030 38 Though Swami Vivekananda and other modern Hindus did call for greater education in Sanskrit and, in some cases, Hindi as a Sanskritic language suitable for the nation of India. See Corstiaan J.G. van der Burg, "The Place of Sanskrit in Neo-Hindu Ideologies: From Religious Reform to National Awakening," in Houben, Ideology and Status of Sanskrit, 367-81.

39 Swami Chinmayananda, A Manual of Self- 
Unfoldment (Mumbai: Central Chinmaya Mission Trust, 1975, 2000), 159.

${ }^{40}$ Ibid., 159-66.

${ }^{41}$ Chinmayananda, Manual, 188.

${ }^{42}$ Swami Dayananda Saraswati and Helmut Girndt, A Vedantin's View of Christian Concepts: A Dialog between Swami Dayananda Saraswati and Professor Helmut Girndt (Saylorsburg, PA: Arsha Vidya Gurukulam, 1998).

${ }^{43}$ Ibid., 16-18, 54-60.

${ }^{44}$ Ibid., 48-49.

${ }^{45}$ Ibid., 62-63.

${ }^{46}$ Ibid., 63-65.

${ }^{47}$ Catherine Cornille, "Introduction: the Dynamics of Multiple Belonging," in Many Mansions? Multiple Religious Belonging and Christian Identity, ed. Catherine Cornille (Maryknoll, NY: Orbis Books, 2002), 2. http://dx.doi.org/2027/inu.30000087930891 ${ }^{48}$ Ibid., 5-6.

${ }^{49}$ Swami Ishwarananda, "Wisdom of the Sages," Chinmaya Mission, Richmond Hill, Ontario, Canada, 25 August 2007. 